\title{
Gas exchanges and growth of passion fruit under saline water irrigation and $\mathrm{H}_{2} \mathrm{O}_{2}$ application
}

\author{
Elysson M. G. Andrade ${ }^{1}$, Geovani S. de Lima², Vera L. A. de Lima ${ }^{3}$, Saulo S. da Silva ${ }^{3}$ \\ Hans R. Gheyi ${ }^{4} \&$ André A. R. da Silva ${ }^{3}$
}

${ }^{1}$ Faculdade Santa Maria. Cajazeiras, PB, Brasil. E-mail: elyssonmarcks@yahoo.com.br (Corresponding author) - ORCID: 0000-0001-7392-3736

${ }^{2}$ Universidade Federal de Campina Grande/Centro de Ciências e Tecnologia Agroalimentar/Programa de Pós-Graduação em Horticultura Tropical. Pombal, PB, Brasil. E-mail: geovani.soares@pq.cnpq.br - ORCID: 0000-0001-9960-1858

${ }^{3}$ Universidade Federal de Campina Grande/Centro de Tecnologia e Recursos Naturais/Programa de Pós-Graduação em Engenharia Agrícola. Campina Grande, PB, Brasil. E-mail: antuneslima@gmail.com - ORCID: 0000-0001-7495-6935; saulosoares90@gmail.com - ORCID: 0000-0002-1049-6519; andrealisson_cgpb@hotmail.com - ORCID: 0000-0001-9453-1192

${ }^{4}$ Universidade Federal do Recôncavo da Bahia/Núcleo de Engenharia de Água e Solo. Cruz das Almas, BA, Brasil. E-mail: hans@pq.cnpq.br - ORCID: 0000-0002-1066-0315

\begin{abstract}
The study was carried out to evaluate the photosynthetic efficiency and growth of yellow passion fruit, cultivated under different levels of irrigation water salinity and exogenous application of hydrogen peroxide. The experiment was carried out in greenhouse of the Universidade Federal de Campina Grande, PB, Brazil, using drainage lysimeters with capacity for $100 \mathrm{dm}^{3}$, filled with Entisol of sandy texture. The experimental design was randomized blocks using a 4 x 4 factorial scheme, with three repetitions, corresponding to four water salinity $\left(0.7 ; 1.4 ; 2.1\right.$ and $\left.2.8 \mathrm{dS} \mathrm{m}^{-1}\right)$ and four concentrations of hydrogen peroxide $(0,20,40$ and $60 \mu \mathrm{M})$. The different concentrations of hydrogen peroxide were applied by soaking the seed for a period of $24 \mathrm{~h}$ and spraying the leaves on the adaxial and abaxial sides. At 35 days after transplanting, the interaction between water salinity and hydrogen peroxide concentrations did not significantly interfere with plant physiology and growth, except for the number of leaves. The hydrogen peroxide did not cause significant effects on any of the evaluated plant variables. Increasing salinity of irrigation water led to reduction in gas exchanges at 61 and 96 days after transplanting. Water salinity inhibited the $\mathrm{CO}_{2}$ assimilation, transpiration, stomatal conductance, instantaneous carboxylation efficiency and stem diameter of passion fruit plants.
\end{abstract}

Key words: Passiflora edulis, antioxidant enzyme, salinity

\section{Trocas gasosas e crescimento do maracujazeiro sob irrigação com águas salinas e aplicação de $\mathrm{H}_{2} \mathrm{O}_{2}$}

RESUMO: O trabalho foi realizado com o objetivo de avaliar a eficiência fotossintética e crescimento do maracujazeiro amarelo, cultivado sob diferentes níveis de salinidade da água de irrigação e aplicação exógena de peróxido de hidrogênio. $O$ experimento foi conduzido em casa de vegetação da Universidade Federal de Campina Grande, PB, utilizando-se lisímetros de drenagem, com capacidade de $100 \mathrm{dm}^{3}$ preenchidos com Entisol de textura franco-arenosa. O delineamento experimental foi em blocos casualizados empregando o esquema fatorial 4 × 4, com três repetições, sendo quatro águas salinas $\left(0,7 ; 1,4 ; 2,1\right.$ e 2,8 dS m m $^{-1}$ e quatro concentrações de peróxido de hidrogênio $(0,20,40$ e $60 \mu \mathrm{M})$. As distintas concentrações de peróxido de hidrogênio foram aplicadas via embebição da semente por um período de $24 \mathrm{~h}$ e pulverização das folhas nas faces adaxial e abaxial. Aos 35 dias após o transplantio, a interação salinidade da água $\times$ concentrações de peróxido de hidrogênio não interferiu significativamente sobre a fisiologia e o crescimento das plantas, exceto sobre o número de folhas. O peróxido de hidrogênio não exerceu efeitos significativos em nenhuma das variáveis avaliadas das plantas. $\mathrm{O}$ aumento da salinidade da água de irrigação promoveu redução nas trocas gasosas aos 61 e 96 dias após o transplantio. A salinidade das águas inibiu a assimilação de $\mathrm{CO}_{2}$, transpiração, condutância estomática e eficiência instantânea da carboxilação e o diâmetro caulinar das plantas.

Palavras-chave: Passiflora edulis, enzima antioxidante, salinidade 


\section{INTRODUCTION}

Passion fruit is cultivated in countries of tropical and subtropical climate, belonging to the Passifloraceae family, of the genus Passiflora (Coelho et al., 2016). In Brazil, the yellow passion fruit (Passiflora edulis F.) in 2016 was cultivated in 49,889 ha and $703,489 \mathrm{t}$ were harvested, with mean yield of $14.10 \mathrm{t} \mathrm{ha}^{-1}$ (IBGE, 2016). Brazil is the world's largest producer and consumer of passion fruit, mainly due to the favorable edaphoclimatic conditions for its growth, development and production of tasty fruits (Mendonça et al., 2006).

In passion fruit cultivation, irrigation promotes quantitative and qualitative gains, due to increases in the levels of yield, uniformity, continuity of production and improvements in external and internal attributes of the fruits (Freire et al., 2010). However, in the semiarid region of Northeast of Brazil, the occurrence of waters with high salinity is common and becomes an obstacle for the establishment of crops in this region (Cavalcante et al., 2011), because excess of salts in the irrigation water causes several effects on plants, especially reduction in the osmotic potential of the soil solution, nutritional imbalance due to the high ionic concentration, particularly sodium, inhibiting the absorption of other nutrients, and the toxic effect of ions, mainly chloride, sodium and boron (Bosco et al., 2009).

Some studies have been carried out and highlight the negative effects of salinity on passion fruit, such as Freire et al. (2012), who evaluated the growth of plants under salt stress and biofertilization in protected environment subjected to water restrictions and found inhibition of plant growth regardless of biofertilizer addition, as well as Bezerra et al. (2016), who recorded a reduction in the growth of 'BRS Sol do Cerrado' and 'Redondo Amarelo' passion fruit genotypes subjected to irrigation with high-salinity water.

Investing in the development of research aimed at seeking other alternatives to mitigate the negative effects of water with high levels of salts on crops is a necessity. Among the mechanisms used to attenuate salt stress on plants, acclimation stands out, which consists of a process in which the previous exposure of seeds and/or plants to a certain type of stress causes metabolic changes that are responsible for increasing its tolerance to a new exposure to the stress (Gondim et al., 2011). Thus, exogenous application of low concentrations of hydrogen peroxide $\left(\mathrm{H}_{2} \mathrm{O}_{2}\right)$ emerges as a viable alternative for acclimation to minimize the problems caused by salt stress. Studies have reported beneficial action of the application of low $\mathrm{H}_{2} \mathrm{O}_{2}$ doses, such as Azevedo Neto et al. (2005) in the pre-treatment of maize seedlings and Wahid et al. (2007) in pre-treatment of wheat seeds to induce tolerance to salinity.

In the literature, there are few reports on the use of peroxide in yellow passion fruit. Thus, due to the socioeconomic importance of this crop in the various producing regions of Brazil and the effects caused by salinity, especially in Northeast of Brazil, it is essential to identify techniques that favor its cultivation under semiarid conditions. This study aimed to evaluate the effects of exogenous application of $\mathrm{H}_{2} \mathrm{O}_{2}$ on the gas exchanges and growth of yellow passion fruit irrigated with saline water.

\section{Material and Methods}

The study was conducted between September 2017 and April 2018 under greenhouse conditions, at the Centro de Tecnologia e Recursos Naturais da Univerisdade Federal de Campina Grande (CTRN/UFCG), Campina Grande, PB, Brazil, located by the geographic coordinates $7^{\circ} 15^{\prime} 18^{\prime \prime} \mathrm{S}, 35^{\circ}$ 52 ' 28 " W and average altitude of $550 \mathrm{~m}$.

The experimental design was randomized blocks in a 4 x 4 factorial arrangement, and treatments resulted from the combination of four irrigation water electrical conductivity $\operatorname{ECw}\left(0.7 ; 1.4 ; 2.1\right.$ and $\left.2.8 \mathrm{dS} \mathrm{m}^{-1}\right)$ and four concentrations of hydrogen peroxide $(0 ; 20 ; 40$ and $60 \mu \mathrm{M})$, with three repetitions, totalizing 48 experimental units, which were constituted by one plant growing in a plastic recipient of $100 \mathrm{dm}^{3}$.

The water salinities were obtained so as to have an equivalent proportion of 7:2:1, for $\mathrm{Na} \mathrm{Ca}: \mathrm{Mg}$, respectively, which prevails in sources of water commonly used for irrigation in small properties of the Northeast region of Brazil (Medeiros, 1992), adjusting to the concentrations of the available supply water.

Irrigation waters were prepared considering the relationship between ECW and the concentration of salts ( $\mathrm{mmol} \mathrm{L}_{\mathrm{c}} \mathrm{L}^{-1}=10^{*} \mathrm{ECw} \mathrm{dS} \mathrm{m}^{-1}$ ), according to Richards (1954). After preparation and calibration of ECw, using a portable conductivity meter, the waters were stored in $200-\mathrm{L}$ plastic pots, properly protected to avoid evaporation, entry and contamination with materials that may compromise its quality.

Treatment with hydrogen peroxide concentrations was performed by soaking the seeds prior to sowing and by spraying the leaves of seedlings on the adaxial and abaxial sides, with the same concentrations ( $167 \mathrm{~mL}$ of $\mathrm{H}_{2} \mathrm{O}_{2}$ solution plant $\left.{ }^{-1}\right)$, at 15day intervals until the flowering stage (when each plot had at least one open flower) using a backpack sprayer.

The passion fruit seeds used were those of the yellow variety, traditionally cultivated in the municipality of Nova Floresta, $\mathrm{PB}$, Brazil (6 $\left.6^{\circ} 27^{\prime} 17^{\prime \prime} \mathrm{S} ; 36^{\circ} 12^{\prime} 11^{\prime \prime} \mathrm{W}\right)$ and commonly known as Guinezinho, due to the spots on the rind similar to those existing on the feathers of a bird locally known as 'galinha Guiné' (Helmeted guineafowl - Numida meleagris) (Medeiros et al., 2016). These seeds came from fruits of a commercial orchard, extracted from plants subjected to the mass selection in the above-mentioned municipality and standardized on vigor and health.

To obtain the seedlings, four seeds were planted in pots (Citropote) with capacity for $6 \mathrm{dm}^{3}$, filled with substrate, composed of a mixture of $84 \%$ soil, $15 \%$ sand washed with supply water and $1 \%$ organic compost (earthworm humus). After seedling emergence, which occurred at seven days after sowing, thinning was performed, leaving only the most vigorous plant in each pot, when its main stem had reached $10 \mathrm{~cm}$ height. Since sowing, irrigation was performed with each type of water used to grow the plants and the different concentrations of hydrogen peroxide were applied before sowing, by soaking the seed in water corresponding to each level of salinity, for a period of $24 \mathrm{~h}$, and by spraying the leaves on the adaxial and abaxial sides during the seedling production period, at 30 and 45 days after sowing (DAS). 
At 65 days after sowing, when the main stem was approximately $35 \mathrm{~cm}$ in height, the plants were transplanted to plastic pots, adapted as drainage lysimeters with capacity for $100 \mathrm{dm}^{3}$, filled with a $0.5-\mathrm{kg}$ layer of crushed stone, followed by $100 \mathrm{~kg}$ of an Entisol of sandy texture, collected in the 0-20 $\mathrm{cm}$ layer, from the rural area of the municipality of Lagoa Seca, PB, Brazil.

The chemical and physical characteristics were obtained according to the methodologies proposed by Embrapa (2017): $\mathrm{Ca}^{2+}=1.60 \mathrm{cmol}_{\mathrm{c}} \mathrm{kg}^{-1} ; \mathrm{Mg}^{2+}=3.66 \mathrm{cmol}_{\mathrm{c}} \mathrm{kg}^{-1} ; \mathrm{Na}^{+}=1.60 \mathrm{cmol}_{\mathrm{c}} \mathrm{kg}^{-1}$; $\mathrm{K}^{+}=2.22 \mathrm{cmol}_{\mathrm{c}} \mathrm{kg}^{-1} ; \mathrm{H}^{+}+\mathrm{Al}^{3+}=1.93 \mathrm{cmol} \mathrm{kg}_{\mathrm{c}} \mathrm{kg}^{-1}$; organic matter $=1.36 \% ; \mathrm{P}=6.80 \mathrm{mg} \mathrm{kg}^{-1} ; \mathrm{pH}$ in water $(1: 2.5)=5.90$; electrical conductivity of the saturation extract $=1.0 \mathrm{dS} \mathrm{m}^{-1}$; exchangeable sodium percentage $=1.87 \%$; sand $=733 \mathrm{~g} \mathrm{~kg}^{-1}$; silt $=142 \mathrm{~g} \mathrm{~kg}^{-1} ;$ clay $=125 \mathrm{~g} \mathrm{~kg}^{-1}$; moisture content at $33.42 \mathrm{kPa}$ $=11.98 \mathrm{dag} \mathrm{kg}^{-1}$; moisture content at $1519.5 \mathrm{kPa}=4.32 \mathrm{dag} \mathrm{kg}^{-1}$.

The base of each lysimeter was connected to a $4-\mathrm{mm}$ diameter transparent drain and received a nonwoven geotextile (Bidim OP 30) to avoid clogging by soil material. A plastic bottle was placed below each drain to collect the leachate and estimate water consumption by the plant.

The spacing was $1.50 \mathrm{~m}$ between rows and $2.20 \mathrm{~m}$ between plants, using a trellis system with non-barbed wire $n^{\circ} 14$, set up inside the greenhouse, $2.40 \mathrm{~m}$ from the floor and $1.60 \mathrm{~m}$ from the lysimeter soil. This trellis system served to support passion fruit plants and sisal strings were used to guide plants to the trellis system.

When plants were $1.70 \mathrm{~m}$ tall, their apical buds were pruned to induce the production of the secondary branches, conducted one to each side on the trellis up to a length of $1.10 \mathrm{~m}$. The apical bud was pruned again to induce the production of tertiary branches, which were conducted up to $30 \mathrm{~cm}$ from the soil, forming a curtain and producing inflorescences, which originated the fruits.

During the experimental period, tendrils and branches that were competing for light, water and nutrients were eliminated in order to promote the development of the crop. Since plants were grown in a closed environment (greenhouse), pollination was performed manually from 12:00 h.

Prior to transplanting, the water volume required for the soil to reach field capacity was determined. After transplanting, irrigation was performed every day at 17:00 h, applying in each lysimeter the water according to the treatments, in order to maintain soil moisture close to field capacity. The volume to be applied was determined based on water requirement of plants, estimated by water balance: volume applied minus volume drained in the previous irrigation, plus a leaching fraction of 0.15 .

Fertilization was performed as recommended by São José et al. (2000), applying $250 \mathrm{~g}$ of single superphosphate and $100 \mathrm{~g}$ of potassium chloride before planting. Topdressing fertilization at early flowering (116 DAT) consisted of $150 \mathrm{~g}$ of single superphosphate per plant. Fertilization with nitrogen and potassium was performed monthly, also as topdressing, according to Santos et al. (2001), using ammonium sulfate and potassium chloride as the sources of nitrogen and potassium, respectively. In the vegetative stage of the crop, the ratio of $1 \mathrm{~N}: 1 \mathrm{~K}$ was used, considering the quantity of $10 \mathrm{~g}$ of nitrogen as reference. From the beginning of flowering, the $\mathrm{N}$ dose was elevated to $20 \mathrm{~g}$ and $\mathrm{K}$ dose to $30 \mathrm{~g}$, increasing the $\mathrm{N}: \mathrm{K}$ ratio to $1: 1.5$.

At 61 and 96 days after transplanting (DAT), $\mathrm{CO}_{2}$ assimilation rate $(\mathrm{A})$, transpiration $(\mathrm{E})$, stomatal conductance (gs), internal $\mathrm{CO}_{2}$ concentration (Ci), instantaneous water use efficiency (WUEi) (A/E) and instantaneous carboxylation efficiency (CEi) (A/Ci) were evaluated using the portable photosynthesis meter "LCPro " from ADC BioScientific Ltd.

The growth of passion fruit was evaluated at $8,35,73$ and 105 DAT, through the determination of individual values of stem diameter (SD) at 35, 73 and 105 DAT, using a caliper, and number of leaves (NL) at 35 and 73 DAT, disregarding those smaller than $2 \mathrm{~cm}$. These data were used to obtain the absolute growth rate (AGRsd) and relative growth rate (RGRsd) within the intervals from 8 to 35 , from 8 to 73 and from 8 to 105 DAT, by adapting the procedures presented by Benincasa (2003), according to Eqs.1 and 2.

$$
\begin{gathered}
\text { AGRsd }=\frac{(\mathrm{SD} 2-\mathrm{SD} 1)}{(\mathrm{t} 2-\mathrm{t} 1)} \\
\text { RGRsd }=\frac{(\ln \mathrm{SD} 2-\ln \mathrm{SD} 1)}{(\mathrm{t} 2-\mathrm{t} 1)}
\end{gathered}
$$

where:

AGRsd - absolute growth rate of stem diameter, $\mathrm{mm} \mathrm{d}^{-1}$;

$\mathrm{SD}_{1}$ - stem diameter, $\mathrm{mm}$, at time $\mathrm{t}_{1}$;

$\mathrm{SD}_{2}$ - stem diameter, $\mathrm{mm}$, at time $\mathrm{t}_{2}$;

RGRsd - relative growth rate of stem diameter, $\mathrm{mm} \mathrm{mm}^{-1} \mathrm{~d}^{-1}$; and,

ln - natural logarithm.

The data collected were subjected to analysis of variance by F test at $\mathrm{p} \leq 0.05$ probability level and, when significant, linear and quadratic polynomial regression analysis was performed using the statistical program Sisvar (Ferreira, 2011). When data heterogeneity occurred, verified by the coefficients of variation, exploratory data analysis was performed, with data transformation to $\sqrt{\mathrm{x}}$.

\section{Results AND Discussion}

The interaction between factors $\left(\mathrm{SL} \times \mathrm{H}_{2} \mathrm{O}_{2}\right.$ ) did not significantly interfere with the gas exchange variables analyzed at 61 and 96 DAT (Table 1), and no significant effect ( $p>0.05$ ) was observed by the concentrations of hydrogen peroxide $\left(\mathrm{H}_{2} \mathrm{O}_{2}\right)$. On the other hand, there was significant influence of irrigation water salinity on the variables $\mathrm{CO}_{2}$ assimilation rate (A) and transpiration (E) at 61 and 96 DAT, stomatal conductance (gs) at 61 DAT and instantaneous carboxylation efficiency (CEi) at 96 DAT.

According to the regression equations (Figures 1A, B, C and D), there was a decreasing linear response with reductions of 19.30 and $18.26 \%$ in $\mathrm{A}, 16.01$ and $12.78 \%$ in $\mathrm{E}, 15.37 \%$ in gs and $28.79 \%$ in $\mathrm{CEi}$, per unit increase in the irrigation water electrical conductivity, that is, plants irrigated with $2.8 \mathrm{dS} \mathrm{m}^{-1}$ 
Table 1. Summary of $\mathrm{F}$ test for $\mathrm{CO}_{2}$ assimilation rate (A), transpiration (E), internal $\mathrm{CO}_{2}$ concentration (Ci), stomatal conductance (gs), instantaneous carboxylation efficiency (CEi) and instantaneous water use efficiency (WUEi) of yellow passion fruit under saline water irrigation and exogenous application of hydrogen peroxide, at 61 and 96 days after transplanting

\begin{tabular}{|c|c|c|c|c|c|c|c|c|c|c|c|c|}
\hline \multirow{4}{*}{ Source of variation } & \multicolumn{12}{|c|}{ F Test } \\
\hline & \multicolumn{2}{|c|}{$\bar{A}$} & \multicolumn{2}{|c|}{$\bar{E}$} & \multicolumn{2}{|c|}{$\mathbf{C i}$} & \multicolumn{2}{|c|}{ gs } & \multicolumn{2}{|c|}{ CEI } & \multicolumn{2}{|c|}{ WUE } \\
\hline & \multicolumn{12}{|c|}{ Days after transplanting } \\
\hline & $\overline{61}$ & 96 & 61 & 96 & 61 & 96 & 61 & 96 & $\overline{61}$ & 96 & 61 & 96 \\
\hline Salinity (SL) & $\star \star$ & $\star \star$ & $\star \star$ & * & ns & ns & *夫 & $\mathrm{ns}$ & ns & * & $\mathrm{nS}$ & ns \\
\hline Linear regression & ** & ** & ** & * & ns & * & ** & ns & ns & ** & ns & * \\
\hline Quadratic regression & ns & ns & ns & ns & ns & ns & ns & ns & ns & ns & ns & ns \\
\hline Hydrogen peroxide $\left(\mathrm{H}_{2} \mathrm{O}_{2}\right)$ & ns & ns & ns & ns & ns & ns & ns & ns & ns & ns & ns & ns \\
\hline Interaction $\left(\mathrm{SL} \times \mathrm{H}_{2} \mathrm{O}_{2}\right)$ & ns & ns & ns & ns & ns & ns & ns & ns & ns & ns & ns & ns \\
\hline Blocks & ns & ns & $\star \star$ & ns & ns & ns & ns & ns & ns & ns & * & ns \\
\hline CV (\%) & 15.1 & 15.0 & 12.8 & 17.1 & 19.1 & 17.3 & 16.6 & 20.6 & $41.89^{1}$ & $34.94^{1}$ & 14.1 & 19.8 \\
\hline
\end{tabular}

ns, ${ }^{* *},{ }^{*}$ - respectively not significant, significant at $\mathrm{p} \leq 0.01$ and at $\mathrm{p} \leq 0.05 ;{ }^{1}$ data transformed to $\sqrt{ } \mathrm{X}$

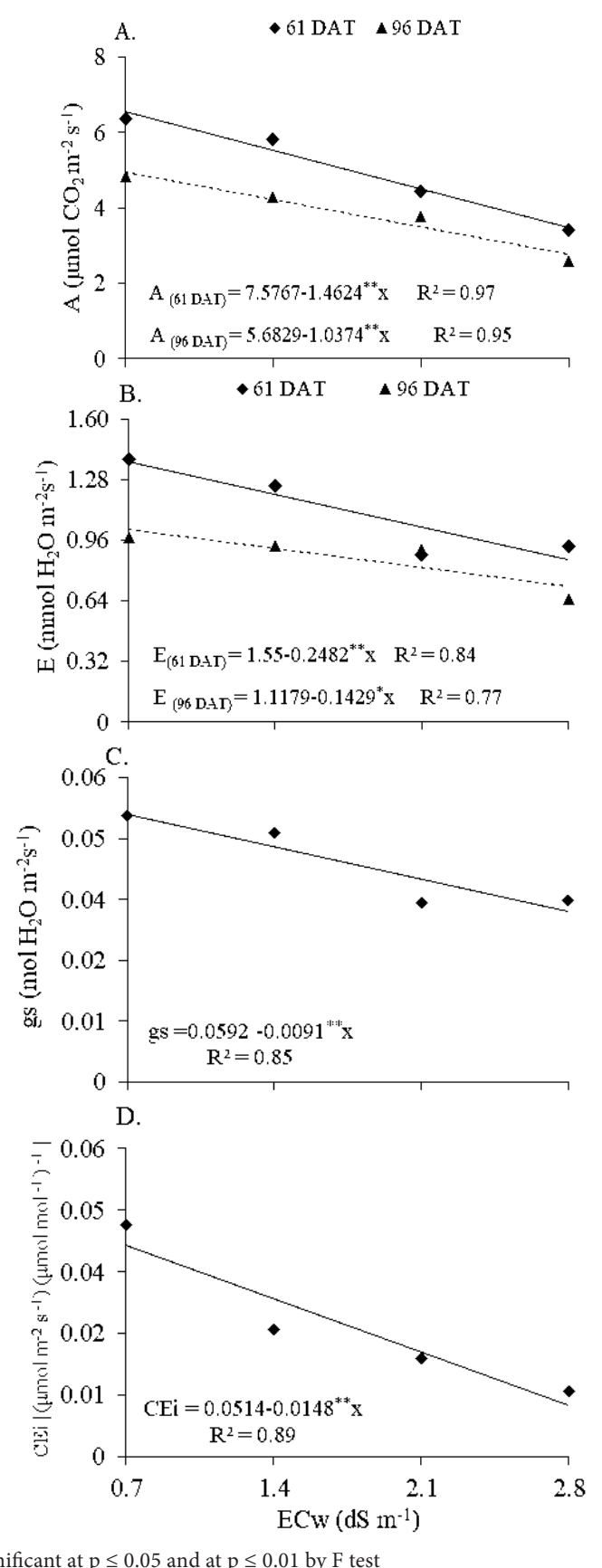

*,** - Significant at $\mathrm{p} \leq 0.05$ and at $\mathrm{p} \leq 0.01$ by $\mathrm{F}$ test

Figure 1. $\mathrm{CO}_{2}$ assimilation rate - $\mathrm{A}(\mathrm{A})$ and transpiration - $\mathrm{E}$ (B) at 61 and 96 DAT, stomatal conductance - gs (C) at 61 DAT and instantaneous carboxylation efficiency - CEi (D) at 96 DAT, in yellow passion fruit under saline water irrigation - ECw water had a reductions of 46.86 and $43.95 \%$ in A, 37.87 and $29.48 \%$ in $\mathrm{E}, 36.17 \%$ in gs and $75.73 \%$ in $\mathrm{CEi}$, compared to plants that received $0.7 \mathrm{dS} \mathrm{m}^{-1}$ water.

These reductions observed in A, E, gs and CEi may be consequences of the osmotic effect caused by the excess of salts in irrigation water, increasing the concentration of salts in the soil. This compromises water absorption by the roots, leading the passion fruit plant to reduce its stomatal opening to avoid water loss, consequently reducing transpiration and also its photosynthetic rate. In a study on quantum yield and gas exchange in yellow passion fruit under water salinity, biofertilization and mulching, Freire et al. (2014) found conflicting results at the beginning of the flowering stage (92 DAT), and the increment in salinity had no influence on $\mathrm{CO}_{2}$ assimilation rate (A), transpiration (E) and stomatal conductance (gs).

The instantaneous carboxylation efficiency (CEi) expresses the relationship between the $\mathrm{CO}_{2}$ assimilation rate $(\mathrm{A})$ and the internal $\mathrm{CO}_{2}$ concentration (Ci). Its reduction observed at $96 \mathrm{DAT}$ can be justified, although not being significant, due to the tendency of increase in $\mathrm{Ci}$ from 169.91 to $221.91 \mu \mathrm{mol} \mathrm{CO} \mathrm{Cm}^{-2} \mathrm{~s}^{-1}$ and of reduction in A from 4.83 to $2.58 \mu \mathrm{mol} \mathrm{CO}_{2} \mathrm{~m}^{-2} \mathrm{~s}^{-1}$, as the salinity of irrigation water increased. Freire et al. (2014) found an increase of $\mathrm{Ci}$ in passion fruit plants under salt stress, in an evaluation at the end of the experiment (214 DAT), attributed to the negative effects of excessive salinity on the carbon metabolism in the plants.

The interaction between the factors $\left(\mathrm{SL} \mathrm{x} \mathrm{H}_{2} \mathrm{O}_{2}\right)$ significantly affected the NL at 35 DAT (Table 2) and there was also a significant effect of irrigation water salinity (SL) on stem diameter at 35, 73 and 105 DAT and on the number of leaves at 35 DAT. However, there was no significant influence of the exogenous application of $\mathrm{H}_{2} \mathrm{O}_{2}$ on the evaluated variables at any period of evaluation.

Stem diameter was negatively affected by the increase in irrigation water salinity at 35, 73 and 105 DAT and, according to the regression equations (Figure 2A), there was decreasing linear response with reductions of $6.58,4.85$ and $9.35 \%$, respectively, i.e., plants irrigated with $2.8 \mathrm{dS} \mathrm{m}^{-1}$ water salinity had reductions of $14.47,10.53$ and $22.3 \%$ compared to plants that were irrigated with $0.7 \mathrm{dS} \mathrm{m}^{-1}$ water. According to Freire et al. (2016), excess of salts in the root zone, in general, cause a depressive effect on plant growth, manifested by a reduction in the rate of transpiration and growth. 
Table 2. Summary of F test for stem diameter (SD) at 35, 73 and 105 days after transplanting (DAT) and number of leaves $(\mathrm{NL})$ at 35 and 73 DAT of yellow passion fruit under saline water irrigation and application of hydrogen peroxide $\left(\mathrm{H}_{2} \mathrm{O}_{2}\right)$

\begin{tabular}{|c|c|c|c|c|c|}
\hline \multirow{4}{*}{ Source of variation } & \multicolumn{5}{|c|}{ F Test } \\
\hline & & SD & & & \\
\hline & \multicolumn{5}{|c|}{ Days after transplanting } \\
\hline & 35 & 73 & 105 & 35 & 73 \\
\hline Salinity (SL) & ** & ๙ & ** & ** & ns \\
\hline Linear regression & ** & * & ** & ns & - \\
\hline Quadratic regression & ns & ns & ns & ** & - \\
\hline Hydrogen peroxide $\left(\mathrm{H}_{2} \mathrm{O}_{2}\right)$ & ns & ns & ns & ns & ns \\
\hline Interaction $\left(\mathrm{SL} \times \mathrm{H}_{2} \mathrm{O}_{2}\right.$ ) & ns & ns & ns & ** & ns \\
\hline Blocks & ** & ns & ns & * & ns \\
\hline CV (\%) & 10.7 & 10.7 & 11.2 & 11.3 & 27.6 \\
\hline
\end{tabular}

ns, ${ }^{* *},{ }^{*}$ respectively not significant, significant at $\mathrm{p} \leq 0.01$ and at $\mathrm{p} \leq 0.05$
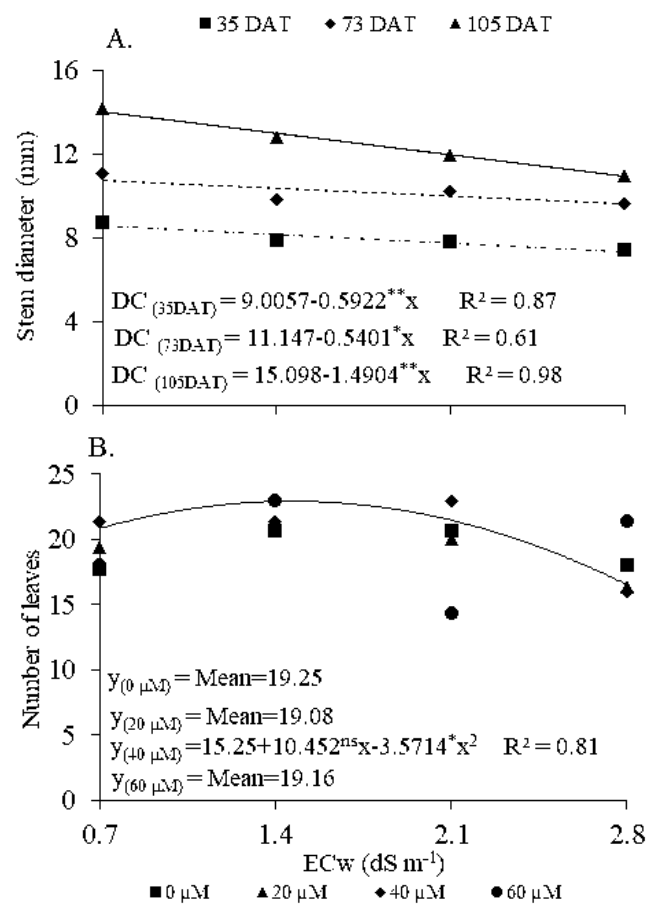

${ }^{*},{ }^{* *}$, ns - Significant at $\mathrm{p} \leq 0.05$ and at $\mathrm{p} \leq 0.01$, and not significat by $\mathrm{F}$ test

Figure 2. Stem diameter - SD (A) of yellow passion fruit, as a function of irrigation with saline waters - ECw, at 35, 73 and 105 days after transplanting (DAT), and interaction between $\mathrm{ECw}$ levels and hydrogen peroxide concentrations for the number of leaves - NL (B), at 35 DAT

According to Munns \& Tester (2008), as soil salinity increases, water availability to the crop decreases, requiring a greater expenditure of metabolic energy in an attempt to maximize the absorption of water from the soil, inhibiting the vegetative growth of the crops, which may have occurred with passion fruit in the present study.

Evaluating the interaction between irrigation water salinity and substrates in the production of yellow passion fruit seedlings, Oliveira et al. (2015) also observed reduction in stem diameter, while variables related to growth and biomass accumulation were increased as the irrigation water salinity levels increased to $3.5 \mathrm{dS} \mathrm{m}^{-1}$. Likewise, Araújo et al. (2013), in a study in the production stage of yellow passion fruit seedlings irrigated with saline waters (ECw ranging from 0.3 to $3.2 \mathrm{dS}$ $\mathrm{m}^{-1}$ ), also found reduction in stem diameter as water salinity increased to $3.2 \mathrm{dS} \mathrm{m}^{-1}$.
The number of leaves (NL) was significantly influenced only by the $40 \mu \mathrm{M}$ concentration of hydrogen peroxide at 35 DAT, according to the regression equation (Figure 2B), and a quadratic model fitted best to the data. The highest estimated value for NL (22.9) was obtained when plants were irrigated with $1.5 \mathrm{dS} \mathrm{m}^{-1}$ water salinity and, from this value, there were reductions in the NL of passion fruit. Thus, it is evident that the effect of salt stress on passion fruit was intensified as the levels of irrigation water salinity increased. This situation may be attributed to the fact that hydrogen peroxide at high concentrations can promote oxidative stress on the crop and, as a consequence, cause changes in cell homeostasis. Hydrogen peroxide is a reactive oxygen species (ROS) and, according to Cattivelli et al. (2008), high concentration of ROS can cause alterations in plant metabolism due to a restriction of photosynthetic processes.

For the other concentrations of hydrogen peroxide, it was not possible to fit any regression model, with mean values of 19.25, 19.08 and 19.16 leaves obtained in plants cultivated under hydrogen peroxide concentrations of 0,20 and $60 \mu \mathrm{M}$, respectively.

The interaction between factors $\left(\mathrm{SL} \times \mathrm{H}_{2} \mathrm{O}_{2}\right.$ ) did not compromise the AGRsd and RGRsd in the evaluated periods (Table 3). However, for the individual factors, there was a significant effect ( $\mathrm{p} \leq 0.01)$ of the irrigation water salinity on AGRsd in the interval from 8 to 105 DAT. For the hydrogen peroxide concentrations, there was no significant influence ( $p>0.05$ ) on AGRsd and RGRsd in the evaluated periods.

Irrigation water salinity negatively affected $(\mathrm{p} \leq 0.01)$ the AGRsd of passion fruit in the interval from 8 to 105 DAT. According to the regression equation (Figure 3), there was a decreasing linear response with reduction of $11.8 \%$ per unit increase in irrigation water electrical conductivity, i.e., plants irrigated with $2.8 \mathrm{dS} \mathrm{m}^{-1}$ water salinity had a $27 \%$ reduction in AGRsd, compared to those that received $\mathrm{ECW}$ of $0.7 \mathrm{dS} \mathrm{m} \mathrm{m}^{-1}$. According to Neves et al. (2009), the contact of the roots with the saline medium contributes to greater and faster absorption of salts, which compromise all plant organs, including the stem.

After irrigation with saline water in soil with bovine biofertilizer cultivated with yellow passion fruit, Dias et al. (2013) observed that the absolute growth rate of stem diameter

Table 3. Summary of $\mathrm{F}$ test for the absolute growth rate (AGRsd) and relative growth rate (RGRsd) of stem diameter (SD) in yellow passion fruit under saline water irrigation and exogenous application of hydrogen peroxide in the periods from 8 to 35,8 to 73 and 8 to 105 days after transplanting

\begin{tabular}{|c|c|c|c|c|c|c|}
\hline \multirow{4}{*}{ Source of variation } & \multicolumn{6}{|c|}{ F Test } \\
\hline & \multicolumn{3}{|c|}{ AGRsd } & \multicolumn{3}{|c|}{ RGRsd } \\
\hline & \multicolumn{6}{|c|}{ Days after transplanting } \\
\hline & $8-35$ & 8-73 & $8-105$ & $8-35$ & $8-73$ & $8-105$ \\
\hline Salinity (SL) & ns & ns & $\star \star$ & ns & ns & ns \\
\hline Linear regression & ns & ns & *夫 & ns & ns & ns \\
\hline Quadratic regression & ns & ns & ns & ns & ns & ns \\
\hline Hydrogen peroxide $\left(\mathrm{H}_{2} \mathrm{O}_{2}\right)$ & ns & ns & ns & ns & ns & ns \\
\hline Interaction $\left(\mathrm{SL} \times \mathrm{H}_{2} \mathrm{O}_{2}\right.$ ) & ns & ns & ns & ns & ns & ns \\
\hline Blocks & ns & ns & ns & ns & ns & ns \\
\hline CV $(\%)$ & 29.9 & 21.3 & 18.8 & 26.5 & 17.6 & 14.7 \\
\hline
\end{tabular}

ns, ${ }^{* *},{ }^{*}$ - Not significant, significant at $\mathrm{p} \leq 0.01$ and $\mathrm{p} \leq 0.05$, respectively by $\mathrm{F}$ test 


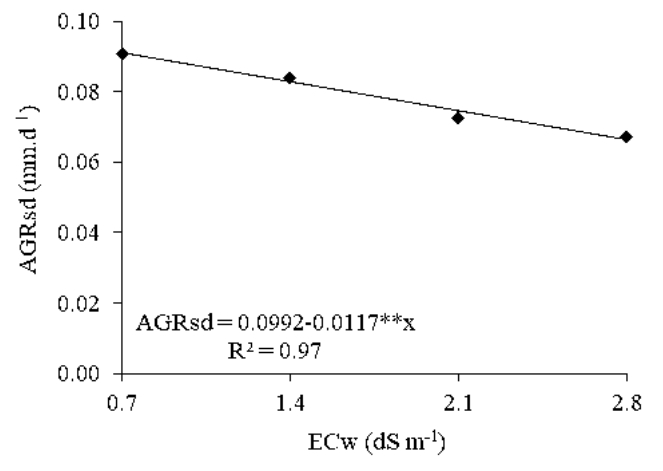

** - Significant at $\mathrm{p} \leq 0.01$ by $\mathrm{F}$ test

Figure 3. Absolute growth rate of stem diameter - AGRsd of yellow passion fruit, as a function of irrigation with saline water - ECw, in the period from 8 to105 days after transplanting

significantly decreased with the increase in irrigation water electrical conductivity above $1.5 \mathrm{dS} \mathrm{m}^{-1}$, up to 157 days after transplanting. Mesquita et al. (2012) also found a decrease in the growth rates for stem diameter of passion fruit seedlings as irrigation water salinity increased.

\section{Conclusions}

1. Except for the number of leaves, at 35 days after transplanting, the interaction (water salinity $\times$ hydrogen peroxide doses) did not significantly interfere with the physiology and growth of passion fruit plants.

2. Hydrogen peroxide doses did not cause significant effects on any of the evaluated variables of passion fruit plants.

3. Water salinity inhibits $\mathrm{CO}_{2}$ assimilation, transpiration, stomatal conductance, instantaneous carboxylation efficiency and stem diameter of passion fruit plants.

\section{Literature Cited}

Araújo, W. L. de; Sousa, J. R. M. de; Sousa Júnior, J. R. de; Aleixo, D. de L.; Pereira, E. B. Produção de mudas de maracujazeiroamarelo irrigadas com água salina. Agropecuária Científica no Semiárido, v.9, p.15-19, 2013.

Azevedo Neto, A. D.; Prisco, J. P.; Enéas Filho, J.; Medeiros, J. V. R.; Gomes Filho, E. Hydrogen peroxide pre-treatment induces salt-stress acclimation in maize plants. Journal of Plant Physiology, v.162, p.1114-1122, 2005. https://doi.org/10.1016/j. jplph.2005.01.007

Benincasa, M. M. P. Análise de crescimento de plantas: Noções básicas. Jaboticabal: FUNEP, 2003. 42p.

Bezerra, J. D.; Pereira, W. E.; Silva, J. M. da; Raposo, R. W. C. Crescimento de dois genótipos de maracujazeiro-amarelo sob condições de salinidade. Revista Ceres, v.63, p.502-508, 2016. https://doi.org/10.1590/0034-737X201663040010

Bosco, M. R. de O.; Oliveira, A. B. de; Hernandez, F. F. F.; Lacerda, C. F. de. Influência do estresse salino na composição mineral da berinjela. Revista Ciência Agronômica, v.40, p.157-164, 2009.

Cattivelli, L.; Rizza, F.; Badeck, F. W.; Mazzucotelli, E.; Mastrangelo, A. M.; Francia, E.; Maré, C.; Tondelli, A.; Stanca, A. M. Drought tolerance improvement in crop plants: An integrated view from breeding to genomics. Field Crops Research, v.105, p.1-14, 2008. https://doi.org/10.1016/j.fcr.2007.07.004
Cavalcante, L. F.; Dias, T. J.; Nascimento, R.; Freire, J. L. de O. Clorofila e carotenoides em maracujazeiro-amarelo irrigado com águas salinas no solo com biofertilizante bovino. Revista Brasileira de Fruticultura, v.33, p.699-705, 2011. https://doi.org/10.1590/ S0100-29452011000500098

Coelho, E. M.; Azêvedo, L. C. de; Umsza-Guez, M. A. Fruto do maracujá: Importância econômica e industrial, produção, subprodutos e prospecção tecnológica. Cadernos de Prospecção, v.9, p.347-361, 2016. https://doi.org/10.9771/cp.v9i3.16637

Dias, T. J.; Cavalcante, L. F.; Pereira, W. E.; Freire, J. L. de O.; Souto, A. G. de L. Irrigação com água salina em solo com biofertilizante bovino no crescimento do maracujazeiro amarelo. Semina: Ciências Agrárias, v.34, p.1639-1652, 2013. https://doi. org/10.5433/1679-0359.2013v34n4p1639

Ferreira, D. F. Sisvar: A computer statistical analysis system. Ciência e Agrotecnologia, v.35, p.1039-1042, 2011. https://doi.org/10.1590/ S1413-70542011000600001

Freire, J. L. de O.; Cavalcante, L. F.; Rebequi, A. M.; Dias, T. J.; Nunes, J. C.; Cavalcante, I. H. L. Atributos qualitativos do maracujá amarelo produzido com água salina, biofertilizante e cobertura morta no solo. Revista Brasileira de Ciências Agrárias, v.5, p.102-110, 2010. https://doi.org/10.5039/agraria.v5ila674

Freire, J. L. O.; Cavalcante, L. F.; Dantas, M. M. M.; Silva, A. G.; Henriques, J. S.; Zuza, J. F. C. Estresse salino e uso de biofertilizantes como mitigadores dos sais nos componentes morfofisiológicos e de produção de glicófitas. Revista Principia, n.29, p. 30-38, 2016. https://doi.org/10.18265/1517-03062015v1n29p29-38

Freire, J. L. de O.; Cavalcante, L. F.; Rebequi, A. M.; Dias, T. J.; Vieira, M. da S.; Crescimento do maracujazeiro amarelo sob estresse salino e biofertilização em ambiente protegido contra perdas hídricas. Holos, v.4, p.55-68, 2012. https://doi.org/10.15628/holos.2012.451

Freire, J. L. de O.; Dias, T. J.; Cavalcante, L. F.; Fernandes, P. D.; Lima Neto, A. J. de. Rendimento quântico e trocas gasosas em maracujazeiro amarelo sob salinidade hídrica, biofertilização e cobertura morta. Revista Ciência Agronômica, v.45, p.82-91, 2014. https://doi.org/10.1590/S1806-66902014000100011

Gondim, F. A.; Gomes Filho, E.; Marques, E. C.; Prisco, J. T. Efeitos do $\mathrm{H}_{2} \mathrm{O}_{2}$ no crescimento e acúmulo de solutos em plantas de milho sob estresse salino. Revista Ciência Agronômica, v.42, p.373-38, 2011. https://doi.org/10.1590/S1806-66902011000200016

IBGE - Instituto Brasileiro de Geografia e Estatística. Produção agrícola municipal, 2016. Available on: <https://sidra.ibge.gov. br/pesquisa/pam/tabelas $>$. Accessed on: Abr. 2018.

Medeiros, J. F. de. Qualidade da água de irrigação utilizada nas propriedades assistidas pelo "GAT" nos Estados do RN, PB, CE e avaliação da salinidade dos solos. Campina Grande: UFPB, 1992. 173p. Dissertação Mestrado

Medeiros, S. A. da S.; Cavalcante, L. F.; Bezerra, M. A. F.; Nascimento, J. A. M. do; Bezerra, F. T. C.; Prazeres, E. da S. Água salina e biofertilizante de esterco bovino na formação e qualidade de mudas de maracujazeiro amarelo. Irriga, v.21, p.779-795, 2016. https://doi.org/10.15809/irriga.2016v21n4p779-795

Mendonça, V.; Araújo Neto, S. E.; Ramos, J. D.; Carvalho, J. G.; Andrade Junior, V. C. Fontes e doses de fósforo para o maracujazeiro-amarelo. Revista Caatinga, v.19, p.65-70, 2006.

Mesquita, F. de O.; Cavalcante, L. F.; Pereira, W. E.; Rebequi, A. M.; Lima Neto, A. J. de; Nunes, J. C. Produção de mudas de maracujazeiro amarelo submetidas à salinidade em solo com biofertilizante bovino. Ciencia del Suelo, v.30, p.31-41. 2012. 
Munns, R.; Tester, M. Mechanisms of salinity tolerance. Annual Review of Plant Biology, v.59, p.631-681, 2008. https://doi. org/10.1146/annurev.arplant.59.032607.092911

Neves, A. L. R.; Lacerda, C. F. de; Guimarães, F. V. A.; Gomes Filho, E.; Feitosa, D. R. C. Trocas gasosas e teores de minerais no feijãode-corda irrigado com água salina em diferentes estádios. Revista Brasileira de Engenharia Agrícola e Ambiental, v.13, p.873-881, 2009. https://doi.org/10.1590/S1415-43662009000700009

Oliveira, F. A. de; Lopes, M. A. C.; Sá, F. V. da S.; Nobre, R. G.; Moreira, R. C. L.; Silva, L. A.; Paiva, E. P. de. Interação salinidade da água de irrigação e substratos na produção de mudas de maracujazeiro amarelo. Comunicata Scientiae, v.6, p.471-478, 2015. https://doi.org/10.14295/cs.v6i4.982

Richards, L. A. Diagnosis and improvement of saline and alkali soils. Washington: U.S. Department of Agriculture, 1954. 160p. https:// doi.org/10.1097/00010694-195408000-00012
Santos, J. B.; Cavalcante, L. F.; Feitosa Filho, J. C.; Lima, E. M.; Santos, C. J. O.; Silva, A. P. P.; Cavalcante, I. H. L.; Alves, G. S. Desenvolvimento vegetativo do maracujazeiro amarelo, em função das relações nitrogênio:potássio e cálcio:magnésio aplicados ao solo. Anais do CPG em Manejo de Solo e Água, v. 23, p. 1-11, 2001.

São José, A. R.; Rebouças, T. N. H.; Pieres, M. M.; Angel, D. N.; Sousa, I. V. B.; Bonfim, M. P. Maracujá: Práticas de cultivo e comercialização. Vitória da Conquista: UESB/DFZ, 2000. $316 \mathrm{p}$.

Wahid, A.; Perveen, M.; Gelani, S.; Basra, S. M. Pretreatment of seed with $\mathrm{H}_{2} \mathrm{O}_{2}$ improves salt tolerance of wheat seedlings by alleviation of oxidative damage and expression of stress proteins. Journal of Plant Physiology, v.164, p.283-294, 2007. https://doi.org/10.1016/j. jplph.2006.01.005 